\title{
Spectrophotometric Determination of Drugs Using Iodine As Analytical Reagent
}

\author{
Sayaji Rao ${ }^{1}$, T. Vinod Kumar ${ }^{2}$, E. Praveen ${ }^{3}$ \\ (1,3 Department of chemistry, Nizam college, Osmania Universiy, Hyderabad,500 001, India) \\ (2 Department of chemistry, Jayaprakash Narayana College of Engineering, Mahabubnagar, A.P)
}

\begin{abstract}
Six drugs viz., Astemizole, Cisapride, Domperidone, Pantoprazole, Rabeprazole and Trazadone were tested for the formation of charge transfer complexes with Iodine. Each of these drugs turned the violet coloured i.e iodine, in $\mathrm{CH}_{2} \mathrm{Cl}_{2}$, to brown and exhibited a new band at $366 \mathrm{~nm}$ in addition to the original band of iodine at $510 \mathrm{~nm}$ due to anion of the reagent whose intensity increased with increase in the concentration of the drugs and formed a basis for quantitative determination of the drugs. The complexes were found to have 1:1 composition and have stability of the order $10^{3}$ to $10^{4}$. The effect of the concentration reagent, polarity of solvent, interference of excipients have been studied and optimized. Dichloroethane (DCE) was found to be suitable solvent for the analysis. The methods have been validated in terms of ICH guidelines and applied to the quantification of pharmaceuticals. The variation of slopes of calibration plots and stability constants of the complexes are discussed in terms of structures of the drugs.
\end{abstract}

Key words. Spectrophotometry, Iodine, Drugs, Quantification, Validation.

\section{Introduction}

Iodine is well known to form ion- pair charge transfer complexes with a variety of aromatic, aliphatic and hereocyclic compounds ${ }^{1-3}$ containing lone pair ( non - bonding ) of electrons on oxygen, sulphur and nitrogen atoms respectively, which act as electron donors and iodine itself acts as $\sigma$ - acceptor. Bonding involved in iodine is $\mathrm{n}-\sigma$ type. Mostly the donors are completely transparent to visible light while iodine absorbs at $510 \mathrm{~nm}$.

Mixing the solution of iodine prepared in DCE with the donors results in a change of violet color of iodine into light brown to pale yellow color and as a consequence, it exhibits a new band at $366 \mathrm{~nm}$ in its absorption spectra in addition to its normal band at $510 \mathrm{~nm}$ (Fig.1) This is attributed due to $\mathrm{I}_{3}{ }^{-}$ion formed by the interaction of iodine with drugs and the same is shown in the following scheme 1.

$$
\begin{aligned}
& \mathrm{D}+\mathrm{I}_{2} \rightarrow \text { D. } \mathrm{I}_{2} \quad \text { (outer complex ) fast } \quad \ldots \ldots \ldots 1 \\
& \text { D. } \mathrm{I}_{2}(\text { outer complex }) \rightarrow\left(\text { D.I }^{+}\right) \mathrm{I}^{-} \text {(inner complex) } \text { slow..2 } \\
& \left(\text { D. } \mathrm{I}^{+}\right) \mathrm{I}^{-}(\text {inner complex })+\mathrm{I}_{2} \rightarrow\left(\text { D. }^{+}{ }^{+}\right)+\mathrm{I}_{3}^{-} \text {fast } \ldots . . .3
\end{aligned}
$$

Scheme-1

Thorough survey of literature on the following drugs revealed that quantification using IODINE as analytical reagent has not been reported yet although the reagent is common, known to offer simple, sensitive method of quantification for drugs. This prompted the authors to develop quantification methods for the following drugs, (Scheme 1), using IODI NE as a chromogen and hence tested them for the formation of charge transfer complexes which is expected to form a basis for the quantification of the drugs The physiological activity of the drugs and methods used so far for their quantification are:

Astemizole (Scheme 2a), chemically 1-[(4-fluorophenyl)methyl]-N-[1-[2-(4- methoxyphenyl)ethyl]4-piperidyl]benzoimidazol-2-amine (Scheme.1a) is a long-acting, selective histamine H1 receptor antagonist. It is a second generation antihistamine in that it does not readily cross the blood-brain barrier. Astemizole is used in the treatment of both seasonal and perennial allergic rhenitis, allergic conjunctivitis, chronic urticaria and other chronic allergies. Because of its physiological significance, it has been quantified by several methods which are enumerated in the recent reference ${ }^{4}$

Cisapride (Scheme 2b) is a gastroprokinetic agent, a drug which increases motility in the upper gastrointestinal tract. It acts as a serotonin $5-\mathrm{HT}_{4}$ receptor agonist and indirectly as a parasympathomimetic. Stimulation of the serotonin receptors increases acetylcholine release in the enteric nervous system. Cisapride increases muscle tone in the esophageal sphincter in people with gastroesophageal reflux disease. It also increases gastric emptying in people with diabetic gastroparesis. It has been used to treat bowel constipation. In many countries it has been either withdrawn or had its indications limited because of reports of the side-effect 
long QT syndrome which predisposes to arrhythmias. Cisapride is official in BP . The reported methods for its determination are reviewed ${ }^{5}$

Domperidone, ((Scheme 2c))chemically is [5-chloro-1-\{1-[3-(2-oxobenzimidazolin-1-yl)-propyl]-4piperidyl\} benzimidazoline-2-one] (Scheme.1b). It is a synthetic benzimidazole compound that acts as a dopamine D2 receptor antagonist. Its localization outside the blood -brain barrier and antiemetic properties has made it is a useful adjunct in therapy for Parkinson's disease. There has been rehabilitated curiosity in antidopaminergic prokinetic agents, a 5-HT4 agonist, from the market. Domperidone is also as a prokinetic negotiator for treatment of upper gastrointestinal motility disorders. It continues to be an attractive alternative to metoclopramide because it has fewer neurological side effects. Patients receiving Domperidone or other prokinetic agents for diabetic gastropathy or gastroparesis should also be managing diet, lifestyle, and other medications to optimize gastric motility.]. Several methods have been reported for determination of Domperidone all of which are reviewed in s recent reference ${ }^{6}$

Pantoprazole sodium sesquihydrate (Scheme 2d) is used as an antiulcerative agent by inhibiting the gastric acid secretion. Pantoprazole sodium sesquihydrate is immensely used for the cure of erosion and ulceration of esophagus caused by a gastroesophageal reflux disease. The literature survey reveals that only few methods are available for the determination of Pantoprazole Sodium in dosage forms and biological materials and are reviewed recently

Rabeprazole sodium(Scheme 2e) is a proton pump inhibitor that suppresses gastric acid secretion by specific inhibition of the enzyme system of hydrogen / potassium adenosine triphosphate $\left(\mathrm{H}^{+} / \mathrm{K}^{+}\right.$ATPase $)$at the secretary surface of the gastric parietal cell. It is indicated for the treatment or symptomatic relief of various gastric disorders gastroesophageal reflux disease and pathological hypersecretory conditions including Zollinger- Ellison syndrome. It is a substituted benzimidazole. Like most compounds of this class, it is decomposed in acid media to yield two main products, the sulfonamide and benzimidazole sulphide. A survey of the literature revealed very few methods for the determination of rabeprazole in pharmaceutical formulations or biological fluids. These methods are recently reviewed ${ }^{8}$

Trazodone (Scheme 2f) is Antidepressant agent. In clinical use the compound has proven to be an antidepressant equivalent in effectiveness to imipramine. Several liquid chromatographic methods are reported for estimation of Trazodone $\mathrm{HCl}$ in various matrix systems? .

\section{Materials}

\section{Experimental}

Iodine (BDH, Poole, UK) was twice sublimed and preserved in vacuum descicator $\left(\mathrm{mp} 113.6^{\circ} \mathrm{C}\right)$. The drugs used in study are procured from various bulk drug and pharmaceutical industries like Hetero drugs, Symed pharma, Neo spark, syn- finechem and Sreenivasa pharma in and around Hyderabad. Most of the drugs procured are in the form of their acid salts. They have been neutralized by adding calculated amount of $\mathrm{NaOH} / \mathrm{NH}_{4} \mathrm{OH}$ as required, followed by extraction with ether or $\mathrm{CHCl}_{3}$. They were recrystallized from suitable solvent till TLC pure. Spectrograde 1,2-Dichloroethane (DCE). Is used without anyfurther purification. AR grade methanol, ether, $\mathrm{NaOH}$ and $\mathrm{NH}_{4} \mathrm{OH}$ all of them are supplied by $\mathrm{S} \mathrm{D}$ fine chemicals, Mumbai.

\section{Extraction of drugs for pharmaceutical analysis.}

\section{Astemizole}

Twenty tablets (Stemiz - 10mg) were finely powdered and mixed. An accurately weighed 50mg of the drug was transferred into a volumetric flask and $50 \mathrm{ml}$ of chloroform was added and shaken well for 5 minutes. The content was filtered using a quantitative filter paper in a beaker. The residue was washed with $20 \mathrm{ml}$ of chloroform. Chloroform was evaporated by heating on water bath. To the content 1,2-dichloroethane or acetonitrile was added and serial dilutions are done accordingly.

\section{Cisapride}

Twenty tablets (Cisad - 10mg) were finely powdered, mixed and an accurately weighed $50 \mathrm{mg}$ of the drug was transferred into a volumetric flask. $50 \mathrm{ml}$ of chloroform was added and shaken well for 5 minutes. The content was filtered using a quantitative filter paper. The residue was washed with $20 \mathrm{ml}$ of chloroform. Chloroform was evaporated by heating on water bath. To the content 1,2-dichloroethane or acetonitrile was added and serial dilutions are done.

\section{Domperidone}

Ten capsules (Domcolic - 10mg) were weighed accurately. The average weight was determined and then ground to a fine powder. A quantity equivalent to $50 \mathrm{mg}$ Domperidone was transferred into a $100 \mathrm{ml}$ volumetric flask. The contents were ultrasonicated for $10 \mathrm{~min}$ with $50 \mathrm{ml}$ of methanol. Then the solution was filtered through a Whatman filter paper (No. 40). The residue was washed with methanol. The methanol is 
evaporated and to the content acetonitrile or 1,2-dichlorethane is added and heated on water bath for sometime for complete dissolution of the drug. Then serial dilutions are done up to the requirements.

4.Pantoprazole

Five tablets (Zovanta $-40 \mathrm{mg}$ ) were weighed accurately. The average weight was determined and then ground to a fine powder. A quantity equivalent to $50 \mathrm{mg}$ of pantoprazole was transferred into a $100 \mathrm{ml}$ volumetric flask. The contents were sonicated for 10 minutes with methanol and filtered through Whatmann filter paper in a beaker. The residue was washed with methanol. The methanol is evaporated and to the content 1,2dichloroethane is added and heated on water bath for sometime for the complete dissolution of the drug. Then serial dilutions are done depending upon the requirements.

\section{Rabeprazole sodium}

Twenty tablets (Razo-10mg) were weighed accurately and a quantity of tablet powder equivalent to $50 \mathrm{mg}$ was weighed and dissolved in the $50 \mathrm{ml}$ of methanol for 5 minutes and volume was filtered through Whatmann filter paper in a beaker. The residue was washed with methanol for the complete recovery of the drug. Methanol was evaporated and the content was dissolved in 1,2-dichloroethane followed by heating for complete dissolution of drug. The content was cooled and was serially diluted for analysis.

\section{Trazadone}

Six tablets (Trazalon-25mg) were powdered and weighed. An amount of the powder equivalent to $100 \mathrm{mg}$ of trazadone was weighed into a $100 \mathrm{ml}$ volumetric flask containing about $75 \mathrm{ml}$ of distilled water. It was shaken thoroughly for about 15-20 min, filtered through a Whatman filter paper No. 40 to remove the insoluble matter. To the clear solution obtained, dilute ammonia solution was added. The drug was separated as solid. The solid was extracted with ether and evaporated on waterbath. The residue obtained was dissolved in acetonintrile or 1,2-dichloroethane which was serially diluted for analysis.

\section{Methods}

The UV-Vis spectra of the individual components and the charge transfer complexes were recorded on Shimadzu 140 or Shimadzu-240 and Elico SL 210 UV- Visible double beam spectrophotometers using a matched pair of quartz cells of $10 \mathrm{~mm}$ path length. The spectra of ion - pair Charge transfer complexes were recorded in $\mathrm{CH}_{2} \mathrm{Cl}_{2}$ for quantification studies as well as to evaluate other parameters like stability constants and stoichiometry of the complexes from absorption studies on characteristic absorption band of anion of the acceptor.

\section{Results and discussion}

Six drugs viz., Astemizole, Cisapride, Domperidone, Pantoprazole, Rabeprazole and Trazadone have positively responded towords Iodine in 1,2- dichloroethane to form ion pair charge transfer complexes as indicated by change of violet color of iodine into light brown to pale yellow and as a consequence, the solutions exhibited a new band at $366 \mathrm{~nm}$ in its absorption spectra in addition to its normal band at $510 \mathrm{~nm}$ (Fig.1) This is attributed due to $\mathrm{I}_{3}{ }^{-}$ion formed by the interaction of iodine with drugs.

\section{PROCEDURE FOR CALIBRATION}

Into separate $10 \mathrm{ml}$ of volumetric flasks different aliquots of each working standard solutions were transferred followed by the addition of $1 \mathrm{ml}$ of iodine solution prepared in 1,2- dichloroethane $\left(2.3 \times 10^{-2} \mathrm{M}\right)$. The volume was completed using the same solvent and the absorbance was measured against reagent blank at 366 and $510 \mathrm{~nm}$ Calibration curves (Fig. 2) were linear for all the drugs whose limits are mentioned in Table1. Slope, intercept, correlation coefficient of the calibration curves are calculated and tabulated.

\section{OPTIMIZATION OF FACTORS AFFECTING THE ABSORBANCE}

\section{1) Effect of concentration of reagent}

The effect of volume of iodine on the absorbance of the product was studied in the range of 0.2, 0.4, $0.6,0.8,1.0,1.2,1.4,1.6,1.8$ and $2.0 \mathrm{ml}$. Acceptor was added to the fixed volume of donors viz.,Pantoprazole 70 $\mu \mathrm{g} / \mathrm{ml}$, Cisapride $75 \mu \mathrm{g} / \mathrm{ml}$, Trazadone $90 \mu \mathrm{g} / \mathrm{ml}$, Astemizole $150 \mu \mathrm{g} / \mathrm{ml}$, Domperidone $260 \mu \mathrm{g} / \mathrm{ml}$ and Rabeprazole $200 \mu \mathrm{g} / \mathrm{ml}$. The absorbance increases with the increase of volume of iodine and becomes constant at $0.8 \mathrm{ml}$. Further dilution does not change the absorbance and therefore, an excess of reagent i.e., $1 \mathrm{ml}$ of iodine was chosen as an optimum value (Fig. 3).

\section{2) Effect of concentration of drug}

To a fixed volume of acceptor mentioned above, different volumes of drug of random concentration were added. Solutions developed coloration. Absorbance was measured at 455, 545, and 588nm. Beer's law was 
obeyed by these solutions to certain extent of concentration and above which linearity was not observed. This concentration is taken as optimum concentration and stock was prepared. The stock was further diluted to get atleast $8-10$ points in calibration curves range.

Similarly when the concentration is below certain limit, points scattered. This was taken roughly as a measure of limit of detection which is further confirmed by following the procedure for determination of LOD and LOQ.

\section{3) Effect of reaction time}

In this method the colored product was formed immediately and remained stable at room temperature for about one hour. The absorbance was measured after 2 minutes of mixing reagent. There is no significant change in the optical densities up to 10 minutes after mixing the components.

\section{4) Effect of organic solvents}

Solvents like Methylene chloride, Chloroform, Carbon tetrachloride were used but found to produce lower absorbance readings (Table 2). Polar solvents like acetonitrile and methanol were found to be unsuitable as their blanks with iodine turned the color of iodine into brown and showed high absorbances even at $366 \mathrm{~nm}$. 1,2- Dichloroethane was found to be an ideal solvent for the formation of a tri-iodide ion pair (inner complex). Hence 1,2- Dichloroethane was used throughout the study.

\section{VALIDATION OF THE PROPOSED METHODS}

The methods developed have been validated in terms of guidelines of international conference of harminisation (ICH) ${ }^{10}$ viz., selectivity, sensitivity, precision, accuracy, linearity, LOD, LOQ Sandell's sensitivity and robustness. The methods are selective and can differentiate the analyte from the excipients. The precision is tested by repeating each experiment at least 6 times while the accuracy has been tested by taking known weight of sample and performing recovery experiments. The values \%RSD and $\mathrm{t}$ - and $\mathrm{F}$ tests are in the permissible range of experimental errors. (Table 3). Sandell's sensitivity "Milligrams of drug per liter required to produce a change in the absorbance by 0.001 absorbance units" have been calculated for all the drugs. Limit of Detection "The lowest amount of analyte in a sample that can be detected, but not necessarily quantitated as an exact value" and Limit of Quantification "The lowest amount of analyte in a sample that can be quantified using Calibration curves" have been calculated by using equations available in the literature.

$$
\begin{gathered}
\mathrm{LOD}=3.3 \mathrm{~s} / \mathrm{S} \\
\mathrm{LOQ}=10 \mathrm{~s} / \mathrm{S} . \\
\begin{array}{c}
(\mathrm{n}=5) \\
\mathrm{S}=\text { slope of Calibration plot }
\end{array}
\end{gathered}
$$

The robustness of the methods are examined by performing the experiments on three different spectrophotometers with excellent tally of absorbance values. The methods developed have also been applied for the analysis of pharmaceuticals. The recovery experiments performed show high accuracy and precision and the results are compared to the available validated reported methods on each drug. The values \%RSD and tand $\mathrm{F}$ tests are in the permissible range of experimental errors. (Table 4) and show that the methods can be used in both pharmaceutical and drug industries

\section{STABILITY CONSTANTS OF ION - PAIR CHARGE TRANSFER COMPLEXES}

In literature the author noticed that Benesi - Hildebrand method (BH) ${ }^{11}$ is widely used for determination of stability constant $K$ and molar absorption coefficient, $\varepsilon$.

$$
\mathrm{Ao} / \mathrm{D}=1 / \mathrm{K}(\mathrm{Do}) \varepsilon+1 / \varepsilon
$$

Above equation is known as $\mathrm{BH}$ equation and a plot of $\mathrm{Ao} / \mathrm{d}$ Vs $1 /$ Do is a straight line from whose slope and intercept the $K$ and $\varepsilon$ are determined. The BH method however demands the concentration of donor Do >> Ao ( Do should be 20 to 100 times the acceptor concentration) and many times the correct separation of $K$ and cis also doubtful.

Many workers used the Benesi - Hildebrand method without fulfilling the condition Do $>>$ Ao and the values of $\varepsilon$ obtained varied widely. The $\varepsilon$ reported for $\mathrm{I}_{3}^{-}$are $2.7 \times 10^{3}$ to $1.46 \times 10^{4} . \mathrm{L} \mathrm{mol}^{-1} \mathrm{~cm}^{-1}$

It is surprising that the molar absorption coefficient of an ion which is expected to be constant and charecteristic of that ion is widely varied. Therefore it is thought worth to determine the molar absorption coefficients of acceptor anions and then use the values to determine the stability constant $K$. To accomplish this, different volumes of dilute solutions of $D D Q$ were transfered to $25 \mathrm{ml}$ standard volumetric flask and excess drug was added and optical density was noted. The addition of drug continued until there is no appreciable increase in the optical density. A plot of d Vs concentration of acceptor gave a straight line from whose slope the molar absorption coefficient of anion of iodine was determined (Fig 4). This experiment was repeated at least with 
three drugs and each experiment was repeated three to four times until constant value of molar absorption coefficient, $\varepsilon$ is found to be 5693 lit mole $\mathrm{cm}^{-1}$. The stability constant $K$

$$
K=(\mathrm{d} / \varepsilon) /[(\mathrm{Ao}-(\mathrm{d} / \varepsilon)][\text { Do }-(\mathrm{d} / \varepsilon)]
$$

is calculated using the molar extinction coefficient obtained from above experiment.

The stoichiometry of each of the complex has been determined from Job's continous variation method and found to be 1:1 in each case. A typical Job's plot of Iodinewith Dextromethorphan is presented in (Fig.5)

\section{Structure activity relation}

From the slopes of calibration curves and stability constants the order of basicity of the drugs towards the iodine is Pantoprazole $>$ Cisapride $\cong$ Trazadone $\cong$ Astemizole $\cong$ Domperidone $>$ Rabeprazole .

From the structures of the drugs it is clear that Pantoprazole having a pyridine with three electron releasing groups is expected to show highest basicity. Cisapride, Trazadone, Astemizole and Domperidone having a $3^{\circ}$ amine groups as a donor sites showed almost equal basicity as evidenced from the slopes of the calibration curves and formation constants of the complexes. Rabeprazole having $\mathrm{N}$-donor sites involved in conjugation showed least basic.

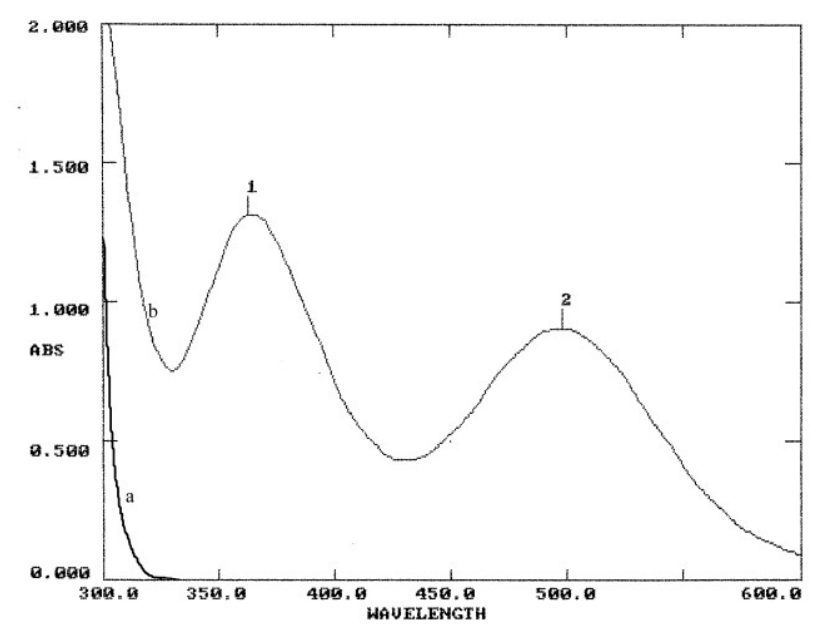

Fig. 1 Absorption spectra of a) Astemizole and b) its charge transfer complex with Iodine

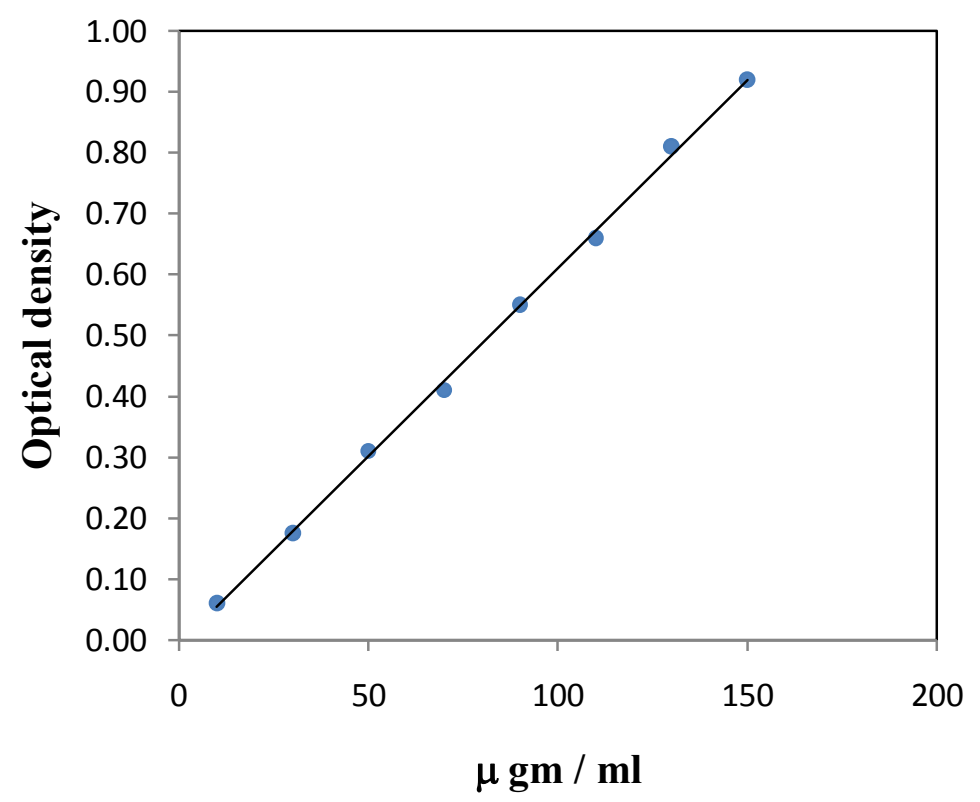

Fig.2 Calibration curve of Astemizole with Iodine 


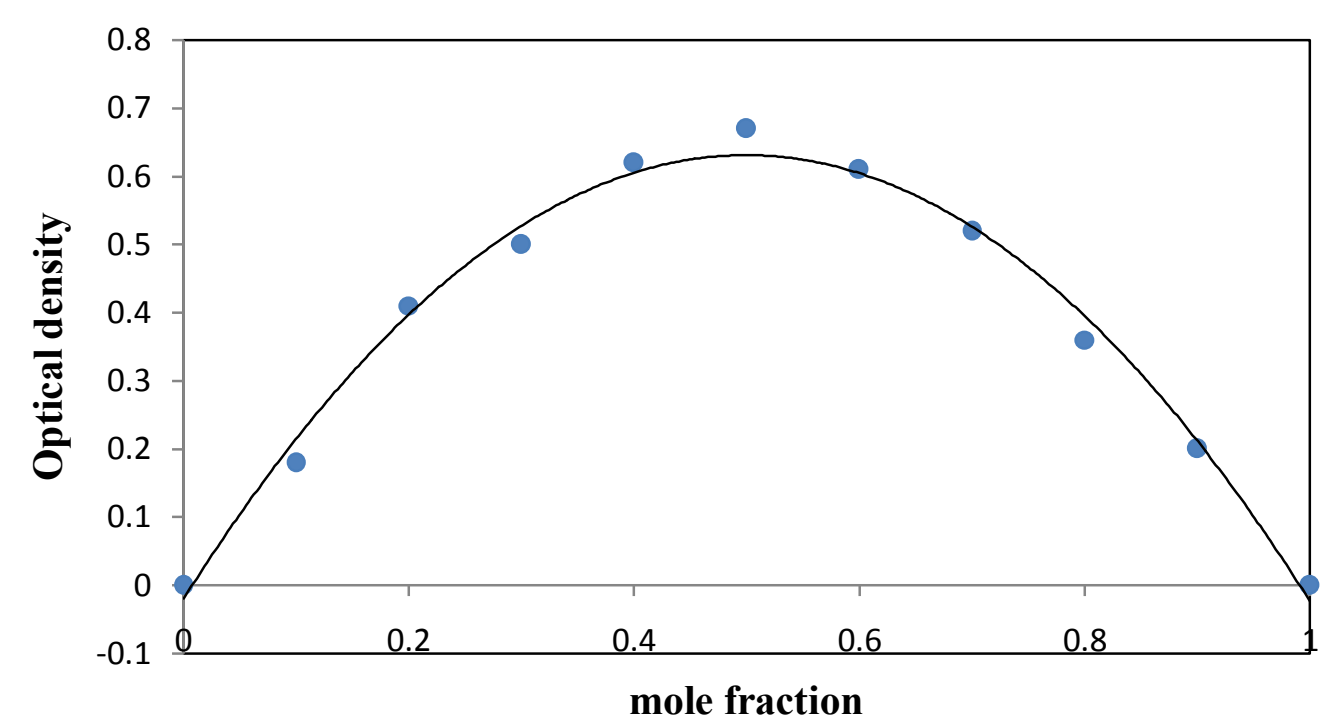

Fig.5 Job's Continuous variation plot of Iodine-Domperidone $\left[\mathrm{A}_{0}\right]=\left[\mathrm{D}_{0}\right]=2.2 \times 10^{-3} \mathrm{M}$

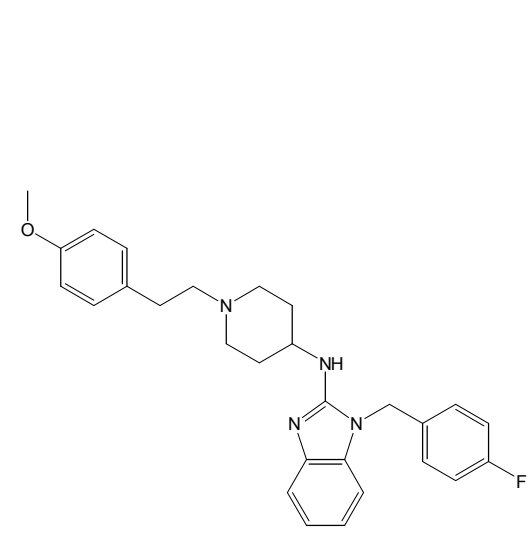

Astemizole

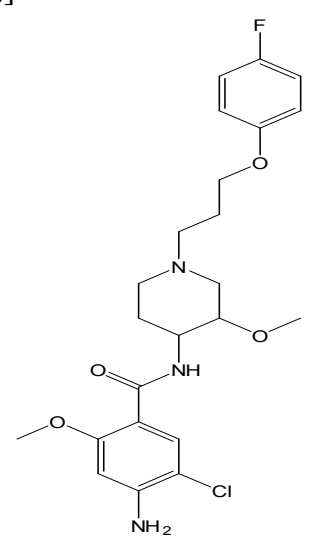

Cisapride

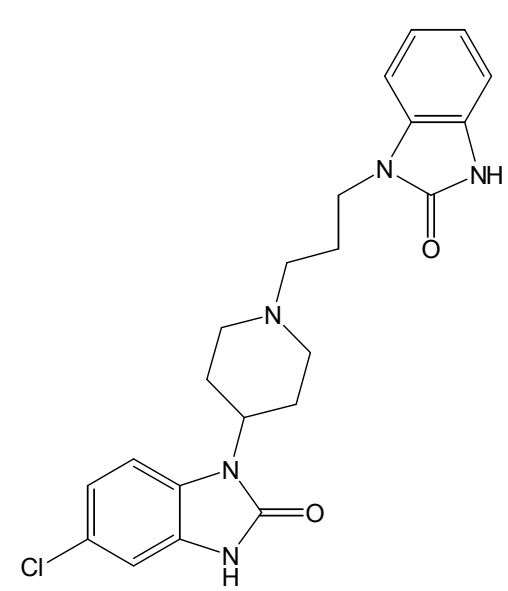

Domperidone<smiles>COCCCOc1ccnc(CS(=O)c2nc3ccccc3[nH]2)c1C</smiles>

Rabeprazole<smiles>O=c1n(CCCN2CCN(c3cccc(Cl)c3)CC2)nc2ccccn12</smiles><smiles>COc1c(C)cnc(CS(=O)(=O)c2nc3cc(OC(F)F)ccc3[nH]2)c1C</smiles>

Pantoprazole

Scheme 1 Structures of drugs 


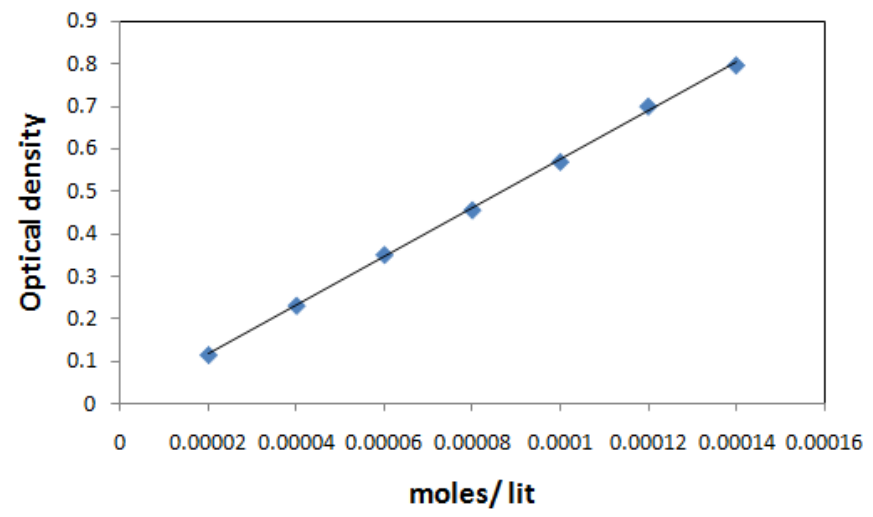

Fig..4 Determination of molar absorption co-efficient of $\mathrm{I}_{3}^{-}$anion

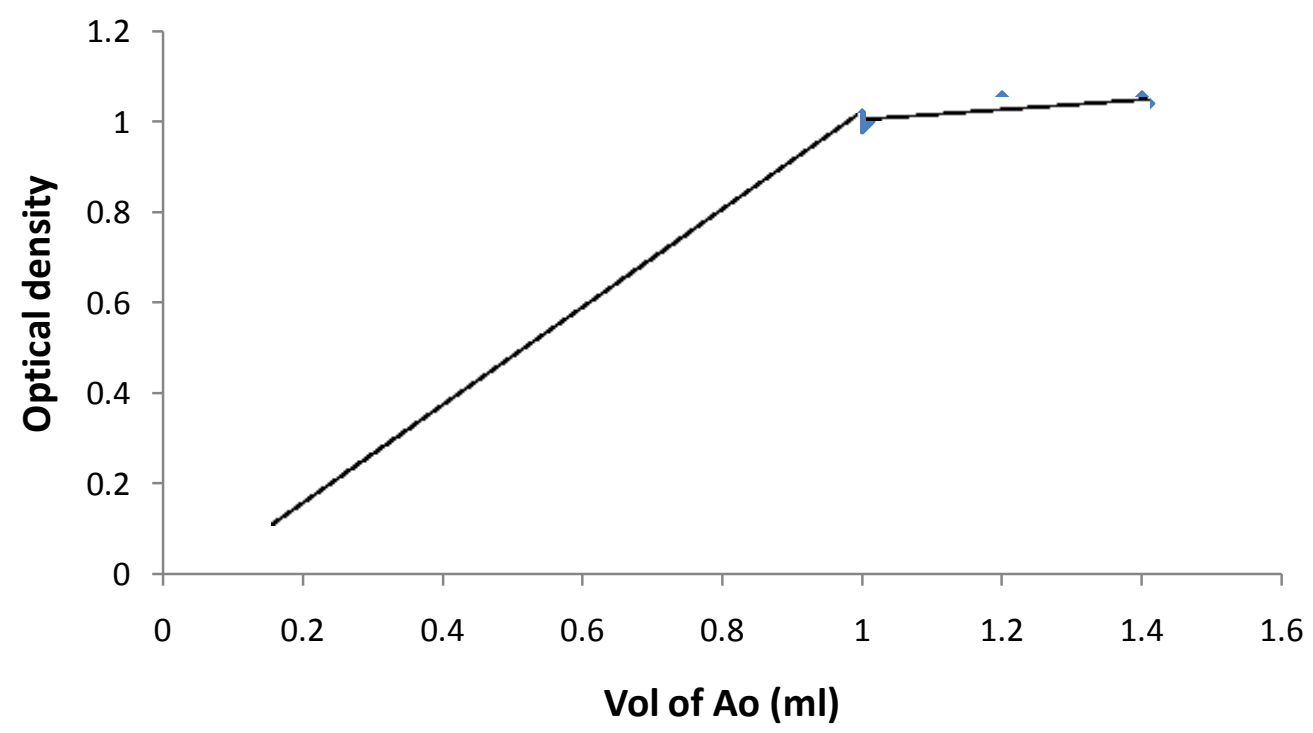

Fig.3 Effect of Reagent volume on the obsorption intensity of the ion-pair Charge transfer complex of Trazadone $(90 \mu \mathrm{gm} / \mathrm{ml})$ with Iodine in 1,2-dichloroethane

Table 1 Spectraland analytical parameters of ion pair complexes of Iodine with drugs

\begin{tabular}{|c|c|c|c|c|c|c|}
\hline Parameter & Ast & Cis & Dom & Pen & $\mathrm{Rab}$ & Tra \\
\hline$\lambda_{\max }(\mathrm{nm})$ & 366 & 366 & 366 & 366 & 366 & 366 \\
\hline $\begin{array}{l}\text { Beer's law limits } \\
\left(\mu \mathrm{gml}^{-1}\right)\end{array}$ & $10-150$ & $5-75$ & $15-260$ & $6-70$ & $22-200$ & $5-90$ \\
\hline $\begin{array}{l}\text { Molar absorptivity } \\
\left(\mathrm{L} \mathrm{mol}^{-1} \mathrm{~cm}^{-1}\right)\end{array}$ & 2790 & 4468 & 1226 & 5150 & 1128 & 4320 \\
\hline $\begin{array}{l}\text { Formation constant } \\
\mathrm{K}, M^{-1}\end{array}$ & $640 \pm 50$ & $1720 \pm 45$ & $125 \pm 10$ & $5400 \pm 60$ & $110 \pm 5$ & $1550 \pm 30$ \\
\hline $\begin{array}{l}\text { Sandell sensitivity } \\
\left(\mu \mathrm{g} \mathrm{cm}^{-2}\right)\end{array}$ & 0.0162 & 0.0885 & 0.2903 & 0.0723 & 0.3134 & 0.0865 \\
\hline Slope b & 0.0062 & 0.0113 & 0.0034 & 0.0138 & 0.0032 & 0.01156 \\
\hline Intercept (a) & -0.0076 & 0.0045 & 0.0062 & -0.0063 & 0.0086 & 0.00152 \\
\hline Correlation coeffici & 0.9994 & 0.9992 & 0.9968 & 0.9998 & 0.9984 & 0.9992 \\
\hline $\begin{array}{l}\text { Standard deviation } \\
\text { of intercepts }(\% n=\end{array}$ & 0.0068 & 0.0026 & 0.0024 & 0.0063 & 0.0026 & 0.0033 \\
\hline $\begin{array}{l}\text { Limit of detection, } \\
{\mu \mathrm{gml}^{-1}}^{-1}\end{array}$ & 3.640 & 0.7575 & 2.3183 & 1.499 & 2.672 & 0.9472 \\
\hline $\begin{array}{l}\text { Limit of quantificat } \\
\mu \mathrm{gml}^{-1}\end{array}$ & 10.921 & 2.2726 & 6.9548 & 4.4974 & 8.016 & 2.8415 \\
\hline $\begin{array}{l}\text { Reegression equatio } \\
\mathrm{Y}=\mathrm{bx}+\mathrm{a}\end{array}$ & $\begin{array}{l}\mathrm{Y}=-0.0076+ \\
\mathrm{x} \text { is } \mathrm{Con} \\
.\left(\mu \mathrm{gml}^{-1}\right)\end{array}$ & $\begin{array}{l}\mathrm{Y}=0.0045 \\
\mathrm{x} \text { is Con } \\
.\left(\mu \mathrm{gml}^{-1}\right)\end{array}$ & $\begin{array}{l}\mathrm{Y}=0.0062+ \\
\mathrm{x} \text { is Con } \\
.\left(\mathrm{\mu gml}^{-1}\right)\end{array}$ & $\begin{array}{l}\mathrm{Y}=-0.0063 \\
+0.0138 \mathrm{x} \\
\mathrm{x} \text { is Con. } \\
\left(\mu \mathrm{gml}^{-1}\right)\end{array}$ & $\begin{array}{l}\mathrm{Y}=0.0086+ \\
\mathrm{x} \text { is Con } \\
\left(\mu \mathrm{gml}^{-1}\right)\end{array}$ & $\begin{array}{l}\mathrm{Y}=0.00152 \\
\mathrm{x} \text { is Con. } \\
\left(\mu \mathrm{gml}^{-1}\right)\end{array}$ \\
\hline
\end{tabular}


Table 2 The effect of solvent on the Optical density of charge transfer band of Iodine with Cisapride

\begin{tabular}{c|c|c}
\hline S.No & Solvent & Optical density \\
\hline 1 & Acetonitrile & 0.84 \\
2 & Methanol & 0.72 \\
3 & 1,2- dichloroethane & \\
4 & Chloroform & 0.15 \\
5 & Carbon tetrachloride & 0.13 \\
& & 0.08 \\
\hline
\end{tabular}

Table 3 Determination of accuracy and precision of the methods on pure drug samples

\begin{tabular}{|c|c|c|c|c|c|c|c|c|}
\hline Drug & $\begin{array}{l}\text { Taken } \\
(\mu \mathrm{g} / \mathrm{ml})\end{array}$ & $\begin{array}{l}\text { Found } \\
(\mu \mathrm{g} / \mathrm{ml})\end{array}$ & $\begin{array}{c}\text { Recovery } \\
(\%)\end{array}$ & $\begin{array}{l}\text { RSD } \\
(\%)\end{array}$ & $\begin{array}{l}\text { Proposed method } \\
\text { Mean } \\
\pm \mathrm{SD}\end{array}$ & $\begin{array}{l}\text { Reference } \\
\text { method } \\
\text { Mean } \\
\pm \text { SD } \\
\end{array}$ & t-test & F-test \\
\hline Ast & $\begin{array}{l}10 \\
50 \\
100 \\
125 \\
150\end{array}$ & $\begin{array}{l}10.06 \\
50.21 \\
98.11 \\
126.23 \\
147\end{array}$ & $\begin{array}{l}100.60 \\
100.42 \\
98.11 \\
100.98 \\
98.00\end{array}$ & $\begin{array}{l}1.14 \\
0.53 \\
0.32 \\
0.78 \\
0.08\end{array}$ & $\begin{array}{l}99.622 \\
\pm 1.44\end{array}$ & $\begin{array}{l}100.29 \\
\pm 1.47\end{array}$ & $\begin{array}{l}1.034 \\
(3.97)\end{array}$ & $\begin{array}{l}0.26 \\
(2.45)\end{array}$ \\
\hline Cis & $\begin{array}{l}10 \\
25 \\
50 \\
75\end{array}$ & $\begin{array}{l}9.946 \\
24.78 \\
49.61 \\
73.598\end{array}$ & $\begin{array}{l}99.46 \\
99.12 \\
99.22 \\
99.13\end{array}$ & $\begin{array}{l}1.21 \\
0.65 \\
0.41 \\
0.69\end{array}$ & $\begin{array}{l}98.98 \\
\pm 0.586\end{array}$ & $\begin{array}{l}99.20 \\
\pm 1.26\end{array}$ & $\begin{array}{l}1.26 \\
(3.97)\end{array}$ & $\begin{array}{l}0.21 \\
(2.23)\end{array}$ \\
\hline Dom & $\begin{array}{l}50 \\
100 \\
150 \\
200 \\
250\end{array}$ & $\begin{array}{l}49.89 \\
99.16 \\
149.67 \\
199.74 \\
245.28\end{array}$ & $\begin{array}{l}99.78 \\
99.16 \\
99.78 \\
99.87 \\
98.11\end{array}$ & $\begin{array}{l}0.98 \\
1.12 \\
0.62 \\
0.59 \\
0.53\end{array}$ & $\begin{array}{l}99.34 \\
\pm 0.7439\end{array}$ & $\begin{array}{l}98.51 \\
\pm 0.58\end{array}$ & $\begin{array}{l}0.607 \\
(3.97)\end{array}$ & $\begin{array}{l}0.874 \\
(2.26)\end{array}$ \\
\hline $\mathrm{Rab}$ & $\begin{array}{l}20 \\
60 \\
100 \\
160 \\
200\end{array}$ & $\begin{array}{l}19.73 \\
58.49 \\
99.48 \\
157.18 \\
197.38\end{array}$ & $\begin{array}{l}107.1 \\
96.20 \\
99.80 \\
100.10 \\
97.33\end{array}$ & $\begin{array}{l}2.07 \\
1.81 \\
1.34 \\
1.00 \\
1.18\end{array}$ & $\begin{array}{l}100.13 \\
\pm 0.08\end{array}$ & $\begin{array}{l}100.60 \\
\pm 0.90\end{array}$ & $\begin{array}{l}1.92 \\
(4.38)\end{array}$ & $\begin{array}{l}2.22 \\
(2.26)\end{array}$ \\
\hline Tra & $\begin{array}{l}10 \\
25 \\
50 \\
75 \\
90\end{array}$ & $\begin{array}{l}9.70 \\
24.83 \\
49.61 \\
74.96 \\
90.08\end{array}$ & $\begin{array}{l}97.00 \\
99.33 \\
99.22 \\
99.95 \\
100.09\end{array}$ & $\begin{array}{l}0.92 \\
0.85 \\
0.75 \\
0.74 \\
0.89\end{array}$ & $\begin{array}{l}99.19 \\
\pm 1.24\end{array}$ & $\begin{array}{l}99.38 \\
\pm 0.84\end{array}$ & $\begin{array}{l}0.457 \\
(3.97)\end{array}$ & $\begin{array}{l}0.15 \\
(2.45)\end{array}$ \\
\hline Pan & $\begin{array}{l}10 \\
20 \\
40 \\
60 \\
70\end{array}$ & $\begin{array}{l}10 \\
19.92 \\
39.59 \\
58.94 \\
67.98\end{array}$ & $\begin{array}{l}100 \\
99.58 \\
98.99 \\
98.24 \\
97.12\end{array}$ & \begin{tabular}{l|}
1.3 \\
1.1 \\
0.93 \\
0.78 \\
0.86
\end{tabular} & $\begin{array}{l}98.79 \\
\pm 1.14\end{array}$ & $\begin{array}{l}98.67 \\
\pm 0.67\end{array}$ & $\begin{array}{l}0.34 \\
(3.97)\end{array}$ & $\begin{array}{l}0.07 \\
(2.31)\end{array}$ \\
\hline
\end{tabular}

\begin{tabular}{|c|c|c|c|c|c|c|c|c|}
\hline Drug & $\begin{array}{l}\text { Taken } \\
(\mu \mathrm{g} / \mathrm{ml})\end{array}$ & $\begin{array}{l}\text { Found } \\
(\mu \mathrm{g} / \mathrm{ml})\end{array}$ & $\begin{array}{c}\text { Recovery } \\
(\%)\end{array}$ & $\begin{array}{l}\text { RSD } \\
(\%)\end{array}$ & $\begin{array}{l}\text { Proposed method } \\
\text { Mean } \\
\pm \text { SD }\end{array}$ & $\begin{array}{l}\text { Reference } \\
\text { method } \\
\text { Mean } \\
\pm \text { SD }\end{array}$ & t-test & F-test \\
\hline Ast & $\begin{array}{l}10 \\
20 \\
30 \\
50 \\
100\end{array}$ & $\begin{array}{l}10.03 \\
20.04 \\
29.36 \\
50.49 \\
97.11\end{array}$ & $\begin{array}{l}100.30 \\
100.20 \\
97.87 \\
100.98 \\
97.11\end{array}$ & $\begin{array}{l}1.01 \\
0.62 \\
0.41 \\
0.73 \\
0.11\end{array}$ & $\begin{array}{l}99.292 \\
\pm 1.69\end{array}$ & $\begin{array}{l}98.8 \\
\pm 2.04\end{array}$ & $\begin{array}{l}1.45 \\
(3.97)\end{array}$ & $\begin{array}{l}0.15 \\
(2.45)\end{array}$ \\
\hline Cis & $\begin{array}{l}10 \\
30 \\
50 \\
60\end{array}$ & $\begin{array}{l}9.946 \\
29.74 \\
50.05 \\
59.41\end{array}$ & $\begin{array}{l}99.46 \\
99.12 \\
100.10 \\
99.01\end{array}$ & $\begin{array}{l}1.21 \\
0.65 \\
0.41 \\
0.69\end{array}$ & $\begin{array}{l}99.423 \\
\pm 0.491\end{array}$ & $\begin{array}{l}99.40 \\
\pm 0.46\end{array}$ & $\begin{array}{l}0.879 \\
(3.97)\end{array}$ & $\begin{array}{l}0.028 \\
(2.23)\end{array}$ \\
\hline Dom & $\begin{array}{l}50 \\
60 \\
70 \\
80 \\
100\end{array}$ & $\begin{array}{l}49.79 \\
58.29 \\
69.15 \\
79.97 \\
99.11\end{array}$ & $\begin{array}{l}99.58 \\
97.16 \\
98.78 \\
99.97 \\
99.11\end{array}$ & $\begin{array}{l}0.98 \\
1.12 \\
0.62 \\
0.59 \\
0.53\end{array}$ & $\begin{array}{l}98.92 \\
\pm 1.083\end{array}$ & $\begin{array}{l}98.93 \\
\pm 1.01\end{array}$ & $\begin{array}{l}0.869 \\
(3.97)\end{array}$ & $\begin{array}{l}0.007 \\
(2.26)\end{array}$ \\
\hline Rab & $\begin{array}{l}20 \\
50 \\
70 \\
100\end{array}$ & $\begin{array}{l}19.73 \\
48.74 \\
69.63 \\
98.24\end{array}$ & $\begin{array}{l}98.67 \\
97.49 \\
99.48 \\
98.24\end{array}$ & $\begin{array}{l}1.24 \\
1.06 \\
0.96 \\
0.83\end{array}$ & $\begin{array}{l}98.82 \\
\pm 1.057\end{array}$ & $\begin{array}{l}98.20 \\
\pm 1.08\end{array}$ & $\begin{array}{l}1.044 \\
(3.97)\end{array}$ & $\begin{array}{l}0.422 \\
(2.26)\end{array}$ \\
\hline
\end{tabular}




\begin{tabular}{|l|l|l|l|l|l|l|l|l|}
\hline & 150 & 150.3 & 100.20 & 0.72 & & & & \\
\hline Tra & 10 & 9.905 & 99.05 & 0.92 & 99.758 & 99.49 & 1.06 & 0.29 \\
& 20 & 19.86 & 99.33 & 0.85 & \pm 0.532 & \pm 0.55 & $(3.97)$ & $(2.45)$ \\
& 30 & 30.07 & 100.24 & 0.75 & & & & \\
& 40 & 40.02 & 100.05 & 0.74 & & & & \\
& 50 & 50.06 & 100.12 & 0.89 & & & & \\
\hline Pan & 10 & 10 & 100 & 1.3 & 99.80 & 99.40 & 1.95 & 0.19 \\
& 20 & 19.92 & 99.58 & 1.1 & \pm 1.058 & \pm 1.48 & $(3.97)$ & $(2.31)$ \\
& 40 & 39.98 & 99.97 & 0.93 & & & & \\
& 50 & 49.13 & 98.25 & 0.78 & & & & \\
& 60 & 60.72 & 101.20 & 0.86 & & & & \\
\hline
\end{tabular}

Table 4Application of the proposed methods for the assay of drugs

\section{References}

[1]. R. Foster, "Organic Charge Transfer Complexes", Academic Press, London and New York, (1969).

[2]. R Foster and I Horman, J. Chem . soc. (B)., (1966) 171.

[3]. M Tamries, Spectroscopy and structure of molecular complexes, (1973) 282.

[4]. C.S.P. Sastry and P.Y. Naidu, Talanta, 45 (1998) 795.

[5]. C.S.P. Sastry, Y. Srinivas and P.V. Subba Rao, Indian J Pharm. Sc., (1996) 169.

[6]. R.B. Kakde, S.N. Gedam, N.K. Chaudhary, A.G. Barsagade, D.L. Kale and A.V. Kasture, Int. J. Pharma tech Res.,1 (2009) 386..

[7]. V. Saini and V.B. Gupta, Int. J. Pharm Tech. Res. 1 (2009) 1094.

[8]. Y Zhang, X Y Chen, Q Gu and D F Zhong, Anal. Chim. Acta., 523 (2004) 171.

[9]. M. R. Ganjali, A. Alipour, S. Riahi and P. Norouzi, Int. J. Electrochem. Sci., 4 (2009) 1153.

[10]. International Conference on hormonization (ICH) of Technical Requirement for the Registration of Pharmaceuticals for Human use, Validation of analytical precedures: definations and Terminology. Genera (1996).

[11]. Benesi H.A.and Hildebrand J.H., A spectrophotometric investigation of the interaction of iodine with aromatic hydrocarbons, J Amer. Chem. Soc, 1949,71(8), 2703-07.

3 Determination of accuracy and precision of the methods on pure drug samples

Table 4 Application of the proposed methods for the assay of drugs

\begin{tabular}{|c|c|c|c|c|c|c|c|c|}
\hline Drug & $\begin{array}{l}\text { Taken } \\
(\mu \mathrm{g} / \mathrm{ml})\end{array}$ & $\begin{array}{l}\text { Found } \\
(\mu \mathrm{g} / \mathrm{ml})\end{array}$ & $\begin{array}{r}\text { Recovery } \\
(\%)\end{array}$ & $\begin{array}{l}\text { RSD } \\
(\%)\end{array}$ & $\begin{array}{l}\text { Proposed method } \\
\text { Mean } \\
\pm \text { SD }\end{array}$ & $\begin{array}{l}\text { Reference } \\
\text { method } \\
\text { Mean } \\
\pm \mathrm{SD}\end{array}$ & t-test & F-test \\
\hline Ast & $\begin{array}{l}10 \\
20 \\
30 \\
50 \\
100\end{array}$ & $\begin{array}{l}10.03 \\
20.04 \\
29.36 \\
50.49 \\
97.11\end{array}$ & $\begin{array}{l}100.30 \\
100.20 \\
97.87 \\
100.98 \\
97.11\end{array}$ & $\begin{array}{l}1.01 \\
0.62 \\
0.41 \\
0.73 \\
0.11\end{array}$ & $\begin{array}{l}99.292 \\
\pm 1.69\end{array}$ & $\begin{array}{l}98.8 \\
\pm 2.04\end{array}$ & $\begin{array}{l}1.45 \\
(3.97)\end{array}$ & $\begin{array}{l}0.15 \\
(2.45)\end{array}$ \\
\hline Cis & $\begin{array}{l}10 \\
30 \\
50 \\
60\end{array}$ & $\begin{array}{l}9.946 \\
29.74 \\
50.05 \\
59.41\end{array}$ & $\begin{array}{l}99.46 \\
99.12 \\
100.10 \\
99.01\end{array}$ & $\begin{array}{l}1.21 \\
0.65 \\
0.41 \\
0.69\end{array}$ & $\begin{array}{l}99.423 \\
\pm 0.491\end{array}$ & $\begin{array}{l}99.40 \\
\pm 0.46\end{array}$ & $\begin{array}{l}0.879 \\
(3.97)\end{array}$ & $\begin{array}{l}0.028 \\
(2.23)\end{array}$ \\
\hline Dom & $\begin{array}{l}50 \\
60 \\
70 \\
80 \\
100\end{array}$ & $\begin{array}{l}49.79 \\
58.29 \\
69.15 \\
79.97 \\
99.11\end{array}$ & $\begin{array}{l}99.58 \\
97.16 \\
98.78 \\
99.97 \\
99.11\end{array}$ & $\begin{array}{l}0.98 \\
1.12 \\
0.62 \\
0.59 \\
0.53\end{array}$ & $\begin{array}{l}98.92 \\
\pm 1.083\end{array}$ & $\begin{array}{l}98.93 \\
\pm 1.01\end{array}$ & $\begin{array}{l}0.869 \\
(3.97)\end{array}$ & $\begin{array}{l}0.007 \\
(2.26)\end{array}$ \\
\hline Rab & $\begin{array}{l}20 \\
50 \\
70 \\
100 \\
150\end{array}$ & $\begin{array}{l}19.73 \\
48.74 \\
69.63 \\
98.24 \\
150.3\end{array}$ & $\begin{array}{l}98.67 \\
97.49 \\
99.48 \\
98.24 \\
100.20\end{array}$ & $\begin{array}{l}1.24 \\
1.06 \\
0.96 \\
0.83 \\
0.72\end{array}$ & $\begin{array}{l}98.82 \\
\pm 1.057\end{array}$ & $\begin{array}{l}98.20 \\
\pm 1.08\end{array}$ & $\begin{array}{l}1.044 \\
(3.97)\end{array}$ & $\begin{array}{l}0.422 \\
(2.26)\end{array}$ \\
\hline Tra & $\begin{array}{l}10 \\
20 \\
30 \\
40 \\
50\end{array}$ & $\begin{array}{l}9.905 \\
19.86 \\
30.07 \\
40.02 \\
50.06\end{array}$ & $\begin{array}{l}99.05 \\
99.33 \\
100.24 \\
100.05 \\
100.12\end{array}$ & $\begin{array}{l}0.92 \\
0.85 \\
0.75 \\
0.74 \\
0.89\end{array}$ & $\begin{array}{l}99.758 \\
\pm 0.532\end{array}$ & $\begin{array}{l}99.49 \\
\pm 0.55\end{array}$ & $\begin{array}{l}1.06 \\
(3.97)\end{array}$ & $\begin{array}{l}0.29 \\
(2.45)\end{array}$ \\
\hline Pan & $\begin{array}{l}10 \\
20 \\
40 \\
50 \\
60\end{array}$ & $\begin{array}{l}10 \\
19.92 \\
39.98 \\
49.13 \\
60.72\end{array}$ & $\begin{array}{l}100 \\
99.58 \\
99.97 \\
98.25 \\
101.20\end{array}$ & $\begin{array}{l}1.3 \\
1.1 \\
0.93 \\
0.78 \\
0.86\end{array}$ & $\begin{array}{l}99.80 \\
\pm 1.058\end{array}$ & $\begin{array}{l}99.40 \\
\pm 1.48\end{array}$ & $\begin{array}{l}1.95 \\
(3.97)\end{array}$ & $\begin{array}{l}0.19 \\
(2.31)\end{array}$ \\
\hline
\end{tabular}

